\title{
Gene Regulation in an Ascending Nociceptive Pathway: Inflammation-induced Increase in Preprotachykinin mRNA in Rat Lamina I Spinal Projection Neurons
}

\author{
K. Noguchi ${ }^{\mathrm{a}}$ and M. A. Ruda \\ Neurobiology and Anesthesiology Branch, National Institute of Dental Research, National Institutes of Health, Bethesda, \\ Maryland 20892
}

\begin{abstract}
Tachykinin peptides are distributed widely in the nervous system and have been shown to play a prominent role in nociceptive pathways in the spinal cord and dorsal root ganglia. This study investigated the inflammation-induced response of dorsal horn projection neurons and local circuit neurons expressing preprotachykinin (PPT) mRNA using RNA blot analysis and in situ hybridization histochemistry. To identify projection neurons, fluorogold was injected into the parabrachial area of the brainstem. In laminae I, II and V/VI ipsilateral to inflammation, there was a differential increase in the number of neurons exhibiting PPT mRNA. In lamina I, the number of spinal projection neurons containing PPT mRNA showed a greater than $200 \%$ increase. The identification of spinal projection neurons with inflammation-induced increases in PPT mRNA suggests that tachykinin peptides may act as neurotransmitters in nociceptive CNS projection pathways.
\end{abstract}

The tachykinin family of peptides is characterized by the carboxy-terminal sequence Phe-X-Gly-Leu-Met- $\mathrm{NH}_{2}$ and named for its ability to induce the contraction of gut tissue rapidly. The family includes substance P (SP), neurokinin A (NKA), neuropeptide $\mathrm{K}(\mathrm{NPK})$, neuropeptide $\gamma(\mathrm{NP} \gamma)$, and neurokinin $\mathrm{B}$ (NKB). The mRNAs that encode SP, NKA, NPK, and $\mathrm{NP}_{\gamma}$ are derived from a single gene, the preprotachykinin (PPT) gene (Nawa et al., 1983; Krause et al., 1987), whereas NKB is encoded by a distinct gene (Kotani et al., 1986). Alternative RNA splicing of the PPT gene primary transcript results in the generation of three mRNAs called $\alpha-, \beta-$, and $\gamma$-PPT mRNA. Quantitative analysis of these mRNAs has revealed the constant ratio of $<1$ : 20:80 ( $\alpha: \beta: \gamma$-PPT mRNA) in all tissue of adult rats (Carter and Krause, 1990). SP precursor sequences are encoded by all three PPT mRNAs, whereas the precursor sequences of NKA-related peptides are present only in $\beta$ - and $\gamma$-PPT mRNAs.

Within the tachykinin family, the physiological role of SP in the CNS and PNS has been widely investigated (for review, see Pernow, 1983; Maggio, 1988). In the spinal cord, abundant

\footnotetext{
Received Oct. 11, 1991; revised Jan. 22, 1992; accepted Jan. 28, 1992.

We appreciate the careful review of earlier drafts of the manuscript by Drs. $G$ Bennett, R. Nahin, and R. Dubner. We acknowledge Dr. M. DeLeon for his help with the RNA blot methodology and Dr. R. Nahin for his advice in the use of the fluorogold method.

Correspondence should be addressed to M. A. Ruda, NAB, NIDR, NIH, Building 30, Room B-20, 9000 Rockville Pike, Bethesda, MD 20892.

a Present address: Department of Anatomy II, Wakayama Medical College, 9-27, Wakayama City, Wakayama 640, Japan.

Copyright (C) 1992 Society for Neuroscience $0270-6474 / 92 / 122563-10 \$ 05.00 / 0$
}

levels of SP have been demonstrated using immunohistochemistry (Hokfelt et al., 1975; Gibson et al., 1981; Hunt et al., 1981). Several studies using intrathecal injection (Piercey et al., 1981; Seybold et al., 1982) or iontophoretic injection of SP (Henry, 1976; Randic and Miletic, 1977; Willcockson et al., 1984) provide cvidence that SP activates nociceptive dorsal horn neurons. However, it should be stressed that SP terminals in the superficial dorsal horn are not exclusively of primary afferent origin (Barber et al., 1979). The fact that a significant number of SP fibers survive both surgical and chemical deafferentations and supraspinal transections (Nagy et al., 1980; Hammond and Ruda, 1991) suggests that some dorsal horn SP is of intrinsic origin. Indeed, SP-immunoreactive neurons have been detected in laminae I-VI, the central canal region, and the lateral spinal nucleus (LSN) (Gibson et al., 1981; Hunt et al., 1981; Davis et al., 1984). However, the functional role of intrinsic SP neurons in the dorsal horn is not understood. It is not known whether SP in intrinsic neurons is involved in nociception.

In a rat model of peripheral inflammation and hyperalgesia, subcutaneous injection of a chemical irritant, complete Freund's adjuvant (CFA), is used to induce unilateral hindpaw edema and thermal hyperalgesia (Iadarola et al., 1988). In this model, cutaneous thermal hyperalgesia is assessed by a decrease in withdrawal latency to noxious thermal stimuli (Hargreaves et al., 1988). In this same animal model, an increase in preprodynorphin (PPD) mRNA and dynorphin peptide (Millan et al., 1986; Iadarola et al., 1988; Ruda et al., 1988) and preproenkephalin (PPE) mRNA (Noguchi et al., 1989, 1992) has been identified. Indeed, the PPD and PPE increases have been colocalized to a subpopulation of neurons exhibiting induction of Fos, the peptide product of the immediate-early gene c-fos (Naranjo et al., 1991; Noguchi et al., 1991, 1992). The present study attempts to characterize other neuronal peptides that are upregulated the dorsal horn neurons that express the PPT gene. The upregulation of PPT gene expression in intrinsic neurons following peripheral inflammation and hyperalgesia would suggest an important role of tachykinins in dorsal horn nocicepíive neuronal circuits.

In addition to intrinsic neurons, the participation of tachykinins in dorsal horn projection neurons is relatively unknown (Nahin, 1987; Leah et al., 1988). Previous physiological experiments have revealed that lamina I projection neurons, which project to the mesencephalic parabrachial area (PBA), are almost exclusively nociceptive specific (Hylden et al., 1986, 1989) and therefore have important roles in nociception. Our finding 
that lamina I projection neurons containing PPT mRNA are dramatically upregulated by noxious stimuli suggests a significant role of tachykinins in nociceptive ascending pathways.

\section{Materials and Methods}

Animal procedures. A rat model of peripheral tissue inflammation was used. To induce the inflammation, under halothane anesthesia, the plantar surface of one hindpaw of male Sprague-Dawley rats (200-300 g) was injected subcutaneously with $200 \mu \mathrm{l}$ of a 1:1 emulsion of complete Freund's adjuvant (CFA) and saline (a total of $100 \mu \mathrm{g}$ of Mycobacterium bytyrium; Sigma). The CFA injection produced localized hindpaw inflammation, as characterized by a rapid erythema, edema, and hyperalgesia to heat stimulation, that continued for several days (Iadarola et al., 1988). Rats with unilateral hindpaw inflammation demonstrated normal eating and grooming behavior and normal levels of locomotor activity (Iadarola et al., 1988), but tended to guard the inflamed limb. This model of unilateral inflammation was presented to and approved by the National Institute of Dental Research Animal Care and Use Committee and treatment conformed to the guidelines of the International Association for the Study of Pain (Zimmermann, 1983).

$R N A$ blot analysis. Animals were anesthetized and killed by decapitation $4 \mathrm{~d}$ after hindpaw injection of CFA. A survival time of $4 \mathrm{~d}$ was selected since previous studies in our laboratory have identified a robust response to the inflammation by dorsal horn neurons, which express preprodynorphin mRNA at this time point (Iadarola et al., 1988; Ruda et al., 1988). The L4 and L5 segments of the spinal cord were rapidly removed and divided in half at the midline. The L4,5 spinal segments from naive rats were also removed. Following dissection, the tissue was immediately frozen on dry ice and stored at $-80^{\circ} \mathrm{C}$ until use. Extraction of total RNA was carricd out as described before (DeLeon et al., 1991). We obtained $0.65-0.75 \mu \mathrm{g}$ of $\mathrm{tRNA} / \mathrm{mg}$ of spinal cord tissue. The RNA was fractionated by electrophoresis through a $1.2 \%$ agarose/formaldehyde gel and transferred overnight to a Hybond-N membrane (Amersham $)$ in a solution of $20 \times \mathrm{SSC}(1 \times \mathrm{SSC}=0.15 \mathrm{~mm} \mathrm{NaCl}, 0.015 \mathrm{~mm}$ sodium citrate). After UV cross-linking and baking for $1 \mathrm{hr}$ at $80^{\circ} \mathrm{C}$, the filters were prehybridized for at least $4 \mathrm{hr}$ at $42^{\circ} \mathrm{C}$ and then hybridized to a labeled probe overnight at $42^{\circ} \mathrm{C}$. The oligonucleotide probe consisted of 48 bases complementary to bases $124-171$ of the $\beta$-preprotachykinin mRNA sequence (Krause et al., 1987). The results and conclusions are dependent on the specificity of the PPT oligonucleotide probe used in this study. In addition to the verification described in previous reports using this probe (Young et al., 1986; Warden and Young, 1988), the following observations further support our conclusion of spccific binding of the probe. (1) The probe sequence was chosen so as not to hybridize with other known sequences. (2) Hybridization took place under conditions of high stringency that would preclude crosshybridization, even with related mRNAs. (3) No cell labeling was seen when sections were hybridized with a synthetic probe for mRNA not expressed by dorsal horn neurons (i.e., that which encodes calcitonin gene-related peptide). (4) RNA blot analysis demonstrated a single band in the position of rat PPT mRNA (Krause et al., 1987) with lumbar spinal cord total RNA.

The PPT probe was labeled with ${ }^{32} \mathrm{P}-\mathrm{dATP}$ (New England Nuclear) and terminal deoxynucleotidyltransferase (Bethesda Reserach Laboratory). The spccific activity of the labclcd probe was $3-6 \times 10^{\circ} \mathrm{cpm} / \mu \mathrm{g}$. After hybridization, filters were washed twice at room temperature for $10 \mathrm{~min}$ in $2 \times \mathrm{SSPE}, 0.1 \% \mathrm{SDS}$ followed by two washes at $55^{\circ} \mathrm{C}$ for 15 min in $1 \times$ SSPE, $0.1 \%$ SDS. Autoradiograms obtained with Kodak $\mathrm{X}$-OMAT film were quantitated by densitometric scanning. To control for the amount of RNA loaded onto each lane, the same filters were hybridized to a cDNA encoding cytochrome oxidase (DeLeon et al., 1991). The cytochrome oxidase mRNA was found to show no change in the spinal cord after peripheral inflammation or nerve injury. The RNA blot data were collected from two separate extractions in each of which eight experimental and four naive rats were used. A total of five different filters (three from one extraction and two from the other) were analyzed.

Fluorogold injection. Rats were anesthetized with sodium pentobarbital $(50 \mathrm{mg} / \mathrm{kg}$, i.p.) and placed in a stereotaxic apparatus. Small holes were drilled into the exposed skull, allowing insertion of a Hamilton 10 $\mu l$ syringe into the mesencephalic parabrachial area (PBA) bilaterally. Fluorogold (Fluoro-Chrome Inc.) was injected intermittently for $10 \mathrm{~min}$ until a total volume of $0.2 \mu \mathrm{l}$ of a $2 \%$ solution had been injected into each side. After $10 \mathrm{~d}$, the animals received a unilateral injection of CFA as described above and were processed for in situ hybridization histochemistry (ISHH). The fluorogold was visualized with a Zeiss epifluorcscence microscope and an ultraviolet fluorescent filter set $(395 \mathrm{~nm}$ emission)

In situ hybridization histochemistry. Animals were killed $4 \mathrm{~d}$ after hindpaw injection of CFA by cardiac perfusion with $4 \%$ paraformaldehyde in $0.1 \mathrm{M}$ phosphate buffer (pH 7.4). The L5 spinal cord segment was dissected out and postfixed in the same fixative overnight followed by immersion in $20 \%$ sucrose in phosphate buffer for cryoprotection. After a few days the tissue was frozen with powdered dry ice, cut transversely with a cryostat at $21 \mu \mathrm{m}$, thaw-mounted onto Vectabond (Vector Lab. Inc.) coated slides, and stored at $-80^{\circ} \mathrm{C}$ until ready for use. To begin the in situ hybridization, tissue sections were digested with proteinase $\mathrm{K}\left(1 \mathrm{mg} / \mathrm{ml}, 37^{\circ} \mathrm{C}\right.$, for $30 \mathrm{~min}$; Sigma) in $0.1 \mathrm{M}$ Tris, $0.05 \mathrm{M}$ ethylenediamine tetra-acetic acid $(\mathrm{pH} 8.0)$, rinsed briefly in distilled water followed by $0.1 \mathrm{M}$ triethanolamine (TEA) ( $\mathrm{pH} 8.0$ ), acetylated with $0.25 \%$ acetic anhydrate in $0.1 \mathrm{M}$ TEA $(\mathrm{pH} 8.0)$, and dehydrated through graded ethanols. The hybridization was performed overnight at $37^{\circ} \mathrm{C}$ in a buffer containing $4 \times \mathrm{SSC}, 50 \%$ formamide, $0.12 \mathrm{~m}$ phosphate buffer, $1 \times$ Denhardt's solution, $0.2 \%$ sodium dodecyl sulfate, 250 $\mu \mathrm{g} / \mathrm{ml}$ yeast tRNA, $10 \%$ dextran sulfate, and $100 \mathrm{~mm}$ dithiothreitol with $10^{6} \mathrm{dpm}$ of labeled probe $/ 100 \mu \mathrm{l}$ buffer/slide. The PPT probe was labeled with ${ }^{35} \mathrm{~S}$-labeled deoxyadenosine [ $\alpha$-thio]-triphosphate (New England Nuclear) and terminal deoxynucleotidyltransferase (Bethesda Research Laboratory). The specific activity of the resultant probe was $5-10 \times 10^{8}$ $\mathrm{cpm} / \mathrm{mg}$. Following hybridization, the sections were washed four times for $15 \mathrm{~min}$ each at $55^{\circ} \mathrm{C}$ in $1 \times \mathrm{SSC}, 30 \mathrm{~min}$ at room temperature in $1 \times \mathrm{SSC}$, and briefly in $70 \%$ ethanol, and then dried. For autoradiography, the tissue sections were coated with Kodak NTB3 emulsion (diluted 1:1 with distilled water at $40^{\circ} \mathrm{C}$ ) and exposed for 4-6 weeks in light-tight boxes at $4^{\circ} \mathrm{C}$. After development in D19 (Kodak) and fixing in $24 \%$ sodium thiosulfate, the sections were rinsed in distilled water, dehydrated in a graded alcohol series, cleared in xylene, and coverslipped with Eukitt (Calibrated Instruments Inc.).

Quantification of labeled cells. We counted the number of neurons labeled for PPT mRNA, or fluorogold, or both, in laminae I, II, and V/VI and LSN. The number of PPT neurons in each lamina was recorded ipsilateral and contralateral to the inflammation. The boundaries between laminae were determined using standard criteria (Molander et al., 1984). Background grain densities were obtained for each section from twenty $10 \mu \mathrm{m}^{2}$ areas of emulsion away from labeled neurons. These values were $0.6-1.0$ grains $/ 10 \mu \mathrm{m}^{2}$, and neurons with grain densities at least 10 times higher than the background densities were considered postively labeled for PPT mRNA. The criteria used in this study was arbitrarily selected to be twice as stringent as previous ISHH studies (Harlan et al., 1987; Noguchi et al., 1989). Although the number of neurons expressing PPT mRNA might be underestimated, this high signal-to-noise ratio effectively eliminated from our counts dorsal horn neurons with low constitutive levels of expression and emphasized the number of neurons that had increased levels of PPT mRNA expression as a response to the peripheral inflammation. Preliminary analysis revealed that the fluorogold fluorescence was greatly attenuated after ISHH processing. To facilitate identification and quantification of the fluorogold-labeled cells, fluorescent photographs of all tissue sections were taken just before beginning ISHH. We counted the number of cells labeled for fluorogold and cells double labeled with fluorogold and PPT mRNA under microscopic observation with the help of the fluorescence photographs. Counts were made from two rats in nine randomly selected sections each. The number of cells labeled for PPT mRNA, or both PPT mRNA and fluorogold, per section in individual animals was used to analyze differences between inflamed and control sides (paired $t$ tests). $p<0.05$ was considered significantly different.

\section{Results}

RNA blot analysis demonstrates an increase in PPT $m R N A$ following peripheral inflammation

RNA blot analysis demonstrated a single hybridization band at an appropriate position for rat PPT mRNA. Four days after onset of unilateral peripheral inflammation, a modest increase occurred in the level of PPT mRNA in the hemisegments of the L4,5 spinal cord ipsilateral to the inflammation (Fig. 1 $A$ ). After standardization by reprobing the blot with a cDNA cy- 


$\begin{aligned} & \text { Table 1. Increase of neurons expressing PPT mRNA following } \\
& \text { unilateral inflammation and hyperalgesia }\end{aligned}$
\begin{tabular}{lcc} 
& Ipsilateral & Contralateral \\
\hline Lamina I & $12.8 \pm 0.6^{*}$ & $7.1 \pm 0.5$ \\
Lamina II & $24.6 \pm 1.2^{*}$ & $18.0 \pm 0.9$ \\
Laminae V/VI & $4.2 \pm 0.4^{*}$ & $1.2 \pm 0.2$ \\
LSN & $3.1 \pm 0.3$ & $2.6 \pm 0.3$
\end{tabular}

Numbers in each column indicate mean \pm SE of the number of neurons expressing PPT mRNA per section $(N=18)$ for both animals (paired $t$ test).

${ }^{*} p<0.01$, significant difference in the number of neurons expressing PPT mRNA between the sides ipsilateral and contralateral to the inflammation for each animal. Differences shown were significant for both animals.

tochrome oxidase probe, densitometeric analysis of the RNA blots revealed that the ipsilateral hemisegment showed an $80 \%$ increase in PPT mRNA compared to control tissue of the same spinal segments from naive rats (Fig. $1 B$ ). ANOVA indicated that there was a significant difference between the inflamed side and naive spinal cord tissue, and also between the inflamed and contralateral sides. There was no significant difference between the L4,5 spinal cord tissue contralateral to inflammation and that from naive rats.

\section{ISHH identifies an increase in PPT $m R N A$ in neuronal subpopulations}

ISHH identified numerous dorsal horn neurons expressing PPT mRNA (Figs. 2, 3). Silver grains overlying the cell somata indicated the presence of PPT mRNA-oligonucleotide hybrids. These were variable in number, suggesting differential neuronal expression (Fig. 2). The labeled neurons were concentrated in the superficial dorsal horn (laminae I and II), the neck of the dorsal horn (laminae V/VI), and LSN (Fig. $3 A, B$ ). ISHH for PPT mRNA-expressing neurons was comparable in spinal cord sections from naive animals and the side of the spinal cord contralateral to the inflamed hindpaw. A comparison of the number and intensity of labeled neurons ipsilateral and contralateral to the inflammation was made. As shown in Figure 3, $A$ and $B$, the hybridization signal over neurons in the superficial laminae and the neck of the dorsal horn was increased on the inflamed side compared to the control side. Quantification of neurons expressing PPT mRNA in each area is presented in Table 1. In lamina I, the number of PPT neurons on the side ipsilateral to the inflammation showed an $80 \%$ increase compared to the contralateral side. The most densely labeled neurons (Fig. 2, arrows) were found on the side ipsilateral to the inflammation and concentrated in the middle two-thirds of the superficial laminae, especially lamina I. These densely labeled lamina I neurons were typically larger than the PPT neurons in lamina II. In lamina II, PPT neurons (50-60\% of all PPT neurons) were identified on both sides. Since the neurons in lamina II have high levels of constitutive expression of PPT mRNA, the apparent increase in number of detectable PPT neurons $(37 \%$ increase) was small, although it represented a significant increase over the contralateral side. The number of PPT neurons located in the lateral part of laminae V/VI and the lateral reticulated area showed a $250 \%$ increase on the inflamed side compared to the contralateral side. However, the number of laminae V/VI neurons was relatively small, representing less than $10 \%$ of the total PPT neurons. In the LSN, there were many neurons expressing PPT mRNA, and no significant increase in the number was seen
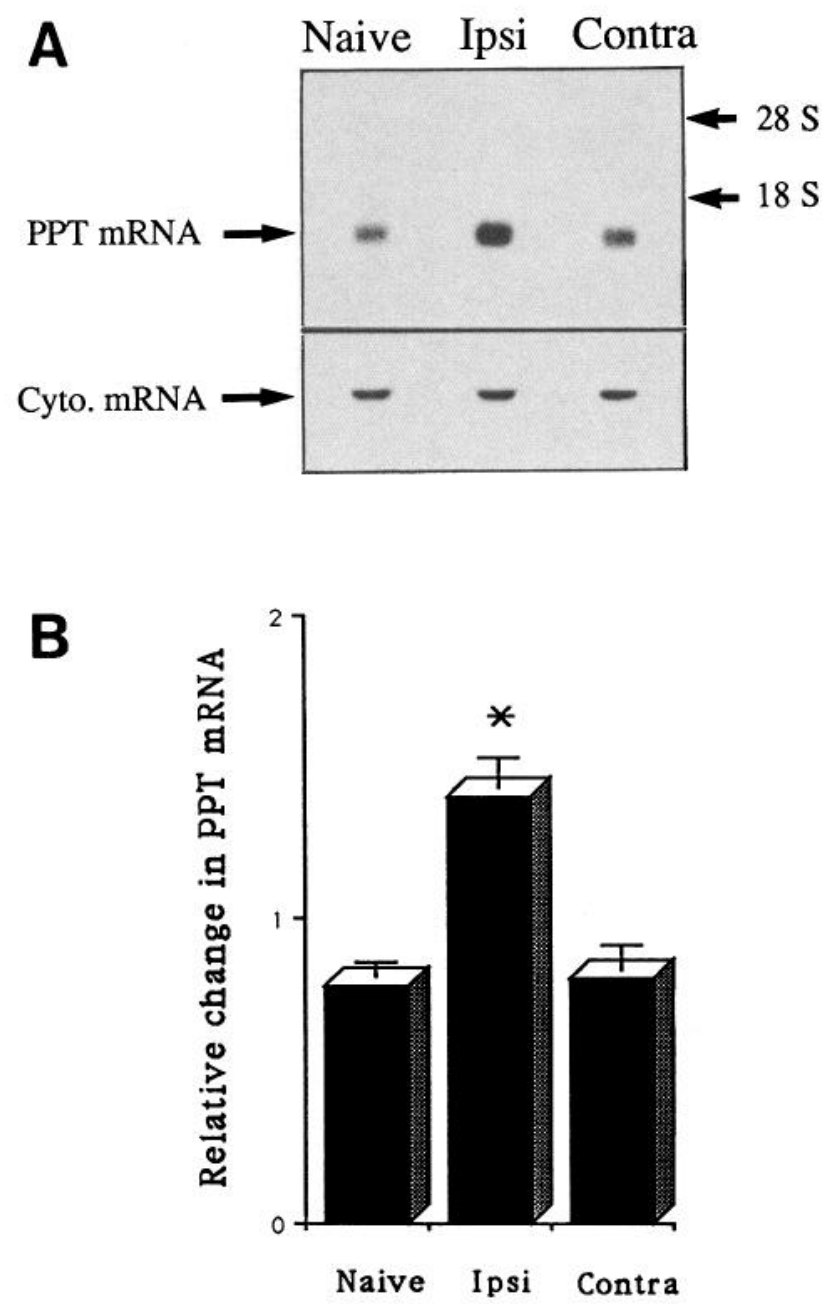

Figure 1. Increased expression of PPT mRNA in rat lumbar spinal cord following peripheral inflammation and hyperalgesia. $A$, RNA blot analysis of $\mathrm{L} 4,5$ spinal cord total RNA $4 \mathrm{~d}$ after peripheral inflammation. The upper panel shows the blot hybridized with a PPT oligonucleotide probe labeled with ${ }^{32} \mathrm{P}-\mathrm{dATP}$, and the lower panel shows the same blot after stripping and hybridization with a cDNA probe for cytochrome oxidase. Locations of the ribosomal RNA are marked. Ipsi, ipsilateral side; Contra, contralateral side. B, Quantification of RNA blot for PPT mRNA in rat lumbar spinal cord. Corrected values of PPT mRNA signal were calculated by dividing the actual PPT mRNA signal, as measured with a computerized densitometer, by the cytochrome oxidase signal obtained from the same lane after reprobing. This was then compared with the corrected value of naive tissue and contralateral side tissue, and is shown as relative levels of PPT mRNA. Values are the mean \pm SE. Five blots were used for quantification. ANOVA showed a significant increase on the side ipsilateral to inflammation compared to naive tissue or the contralateral side. ${ }^{*}, p<0.01$, ANOVA.

ipsilateral to the inflammation. Parasagittal sections through the middle of the dorsal horn, an area of the dorsal horn receiving afferents from the inflamed hindpaw, also demonstrated increases in the levels of PPT mRNA (Fig. $3 C, D$ ). Compared to the contralateral side, there was an increase in signal intensity and the number of PPT neurons in laminae I, II, and V/VI. PPT neurons in the superficial laminae (I and II) were uniformly distributed rostrocaudally, while PPT neurons in laminae V/VI were scattered rostrocaudally. The most densely labeled neurons were found in laminae I and V/VI (Fig. 3D). 


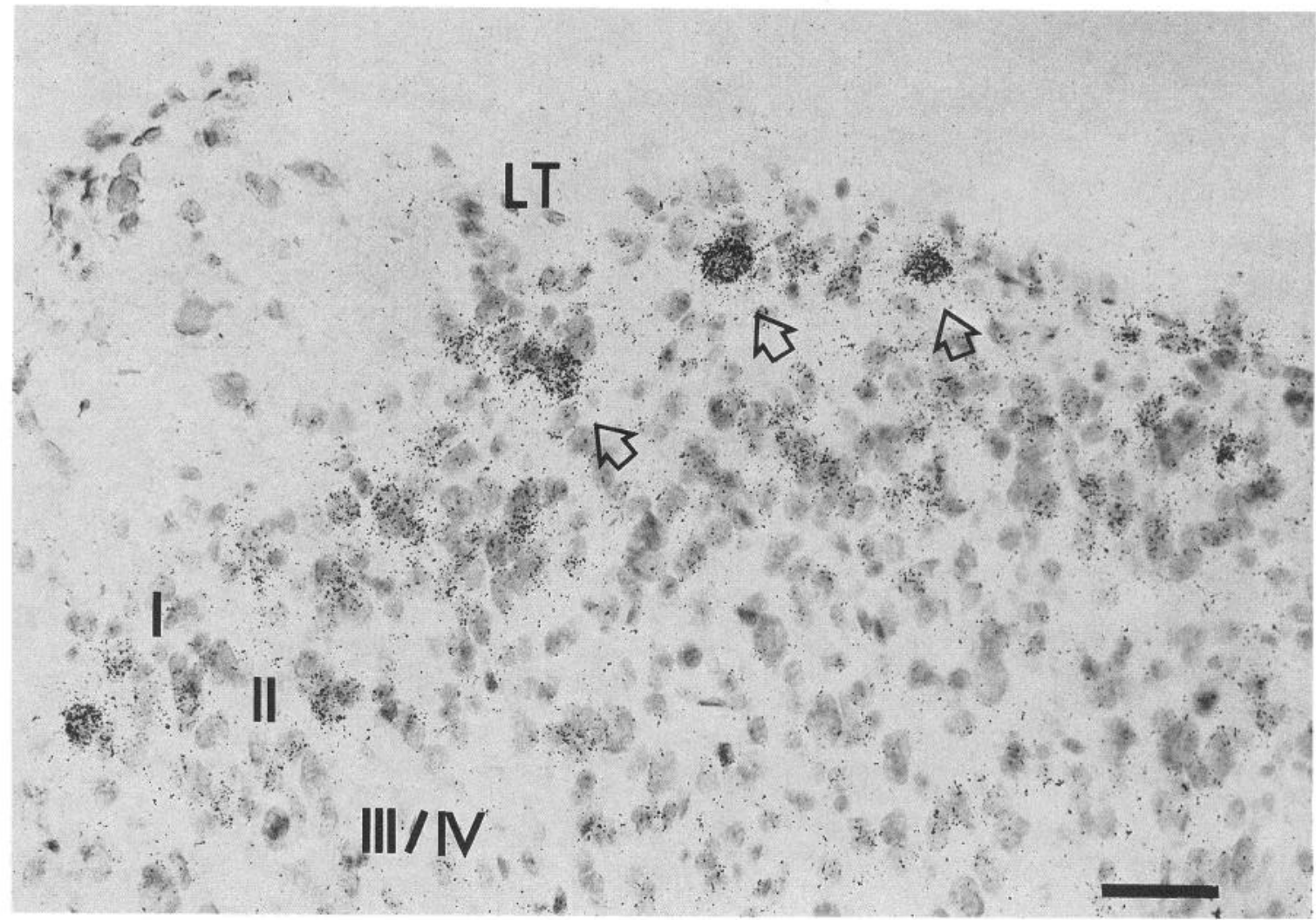

Figure 2. Bright-field photomicrograph of the L5 segment of lumbar spinal cord ipsilateral to the inflammation. Silver grains are aggregated over the somata of many neurons in laminae I and II, indicating the presence of PPT mRNA-oligonucleotide hybrids. The most densely labeled neurons were mainly found in lamina I, often adjacent to Lissauer's tract $(L T)$ on the side ipsilateral to the inflammation (arrows). Scale bar, $50 \mu \mathrm{m}$.

\section{Retrogradely labeled dorsal horn neurons}

Some of the most densely labeled PPT neurons (indicated by arrows in Fig. 2) were found in lamina I. To determine whether these densely labeled neurons projected to the brainstem, the combined methods of ISHH and retrograde labeling with fluorogold were employed. Since the goal of the fluorogold injections was to label as many projection neurons as possible, no attempt was made to restrict the injection site to any one brainstem nucleus. The fluorogold injections were centered in the area surrounding the brachium conjunctivum at the pontomesencephalic junction and included varying portions of the parabrachial nucleus, ventrolateral periaqueductal gray (PAG), and nucleus cuneiformis (Fig. 4). The distribution of fluorogoldlabeled neurons in the L5 segment was similar in all animals and was consistent with previous reports (Hylden et al., 1989). The majority of the labeled projection neurons were located in lamina I and LSN. Some retrogradely labeled neurons were found in the lateral part of lamina $V$ or scattered in laminae IV-VII and X. The cell bodies tended to be clustered under the dorsal root entry zone. The number of fluorogold-labeled neurons in 18 sections showed no significant difference between fluorogold-labeled neurons on the inflamed and contralateral sides (mean \pm SE of number of labeled neurons per section: 6.1 \pm 0.5 ipsilateral, $5.9 \pm 0.4$ contralateral in lamina I; $2.4 \pm 0.4$ ipsilateral, $2.2 \pm 0.3$ contralateral in laminae $\mathrm{V} / \mathrm{VI}$; and $2.7 \pm$ 0.4 ipsilateral, $2.3 \pm 0.3$ contralateral in LSN).

Using the ISHH method with the PPT oligonucleotide probe in conjunction with the retrograde fluorogold tracer, we iden- tified many projection neurons expressing PPT mRNA in lamina I (Fig. 5A-C), lamina V, and LSN (Fig. 5D). The doublelabeled neurons exhibited accumulations of fluorescent fluorogold in the cell body and proximal dendrites, and aggregations of silver grains, indicating PPT mRNA, overlying the cell body. The double-labeled neurons in lamina I were medium sized and bipolar or polygonal cells with their dendrites extending along the superficial border of the dorsal horn (Fig. $5 A, B$ ). Most double-labeled neurons in lamina I were concentrated in the area under the dorsal root entry zone (Fig. 6). An occasional doublelabeled neuron was located in Lissauer's tract (Figs. 5A, 6). The most lateral part of lamina I had few double-labeled neurons. In parasagittal sections, the lamina I fluorogold-labeled neurons expressing PPT mRNA were observed to have rostrocaudally oriented dendrites (Fig. 5C). In laminae V/VI, medium-sized multipolar neurons labeled for fluorogold expressed PPT mRNA (not shown). The double-labeled neurons in the LSN had an intensely fluorescent multipolar cell body and prominent dendritic staining (Fig. 5D).

The number of double-labeled neurons was counted on both sides of the dorsal horn and statistically analyzed (Table 2). The percentage of fluorogold-labeled cells also labeled for PPT mRNA and the percentage of PPT neurons also labeled for fluorogold were calculated. On the side contralateral to the inflammation, a small number of labeled projection neurons in laminae I ( 1.2 cells/section) and V/VI ( 0.2 cells/section) contained PPT mRNA. Twenty-two percent of all fluorogold-labeled neurons in lamina I were double labeled, whereas $8 \%$ of the fluorogold neurons in laminae V/VI expressed PPT mRNA. In the LSN, the number 

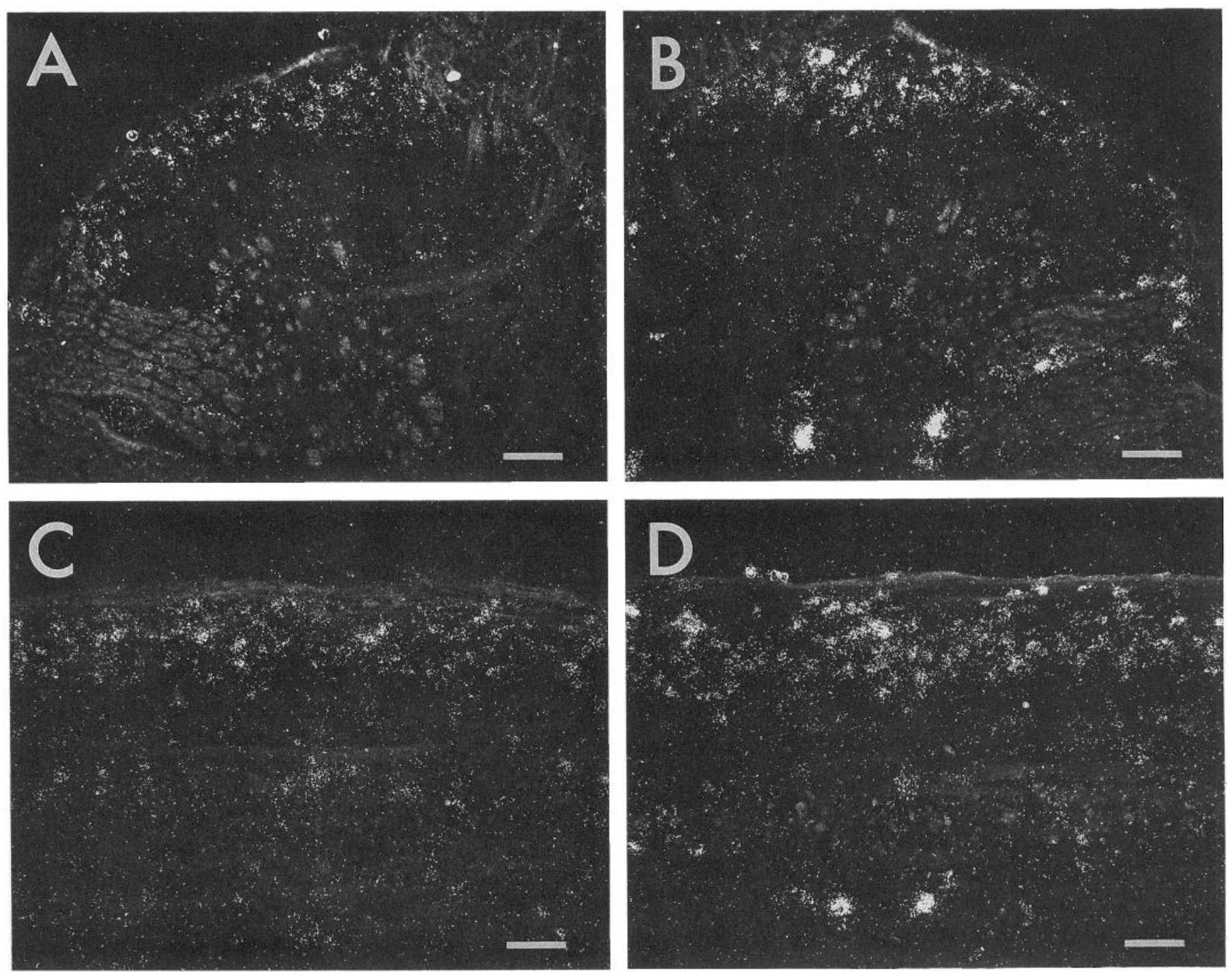

Figure 3. Dark-field photomicrographs of tissue sections from the L5 segment of the lumbar spinal cord contralateral $(A, C)$ and ipsilateral $(B$, $D$ ) to the inflamed paw. $A$ and $B$ are in the transverse plane, while $C$ and $D$ are parasagittal sections through the middle of the dorsal horn. ISHH demonstrates labeled neurons concentrated in laminae I and II and the lateral part of laminae V/VI. A subpopulation of the labeled neurons on the side ipsilateral to the inflammation exhibited increased silver grain density. Scale bars, $100 \mu \mathrm{m}$.

of double-labeled neurons averaged 1.4 per section, which was $61 \%$ of the fluorogold-labeled neurons in the LSN. On the side of the spinal cord ipsilateral to the inflammation, there was a dramatic increase in the number (a greater than $200 \%$ increase compared to the control side) of lamina I neurons labeled for PPT mRNA and fluorogold (Table 2). On average, there were 3.7 double-labeled neurons per section, which was $61 \%$ of fluorogold neurons and $29 \%$ of PPT neurons in lamina I. The net increase of PPT neurons was 5.7 neurons/section $(12.8-7.1$; Table 1), while the net increase of double-labeled neurons was 2.5 neurons/section (3.7 - 1.2; Table 2). In laminae V/VI, although there was a slight increase in double-labeled neurons (0.6 neurons/section), their number was not statistically significant compared to the contralateral side ( 0.2 neurons/section). There was no difference in the number of double-labeled neurons in the LSN ipsilateral and contralateral to the inflammation ( 1.8 cells/section), where they represented $50-60 \%$ of the PPT neurons in the LSN.
Table 2. Increase of spinal projection neurons expressing PPT mRNA following unilateral inflammation and hyperalgesia

\begin{tabular}{lll} 
& Ipsilateral & Contralateral \\
\hline Lamina I & $3.7 \pm 0.3^{*}$ & $1.2 \pm 0.2$ \\
& $(61 \% / 29 \%)$ & $(22 \% / 17 \%)$ \\
Laminae V/VI & $0.6 \pm 0.2$ & $0.2 \pm 0.1$ \\
& $(24 \% / 15 \%)$ & $(8 \% / 14 \%)$ \\
LSN & $1.8 \pm 0.3$ & $1.4 \pm 0.2$ \\
& $(69 \% / 60 \%)$ & $(61 \% / 53 \%)$
\end{tabular}

Numbers in each column indicate mean $\pm \mathrm{SE}$ of the number of fluorogold-labeled cells expressing PPT mRNA per section $(N=18)$ for both animals. Percentages in parentheses: left, the proportion of fluorogold-labeled neurons expressing PPT mRNA in each lamina; right, the proportion of PPT mRNA-expressing neurons labeled for fluorogold in each lamina.

${ }^{*} p>0.01$ (paired $t$ test), significant difference in the number of projection neurons expressing PPT mRNA between the ipsilateral and contralateral sides for each animal. Differences shown were significant for both animals. 


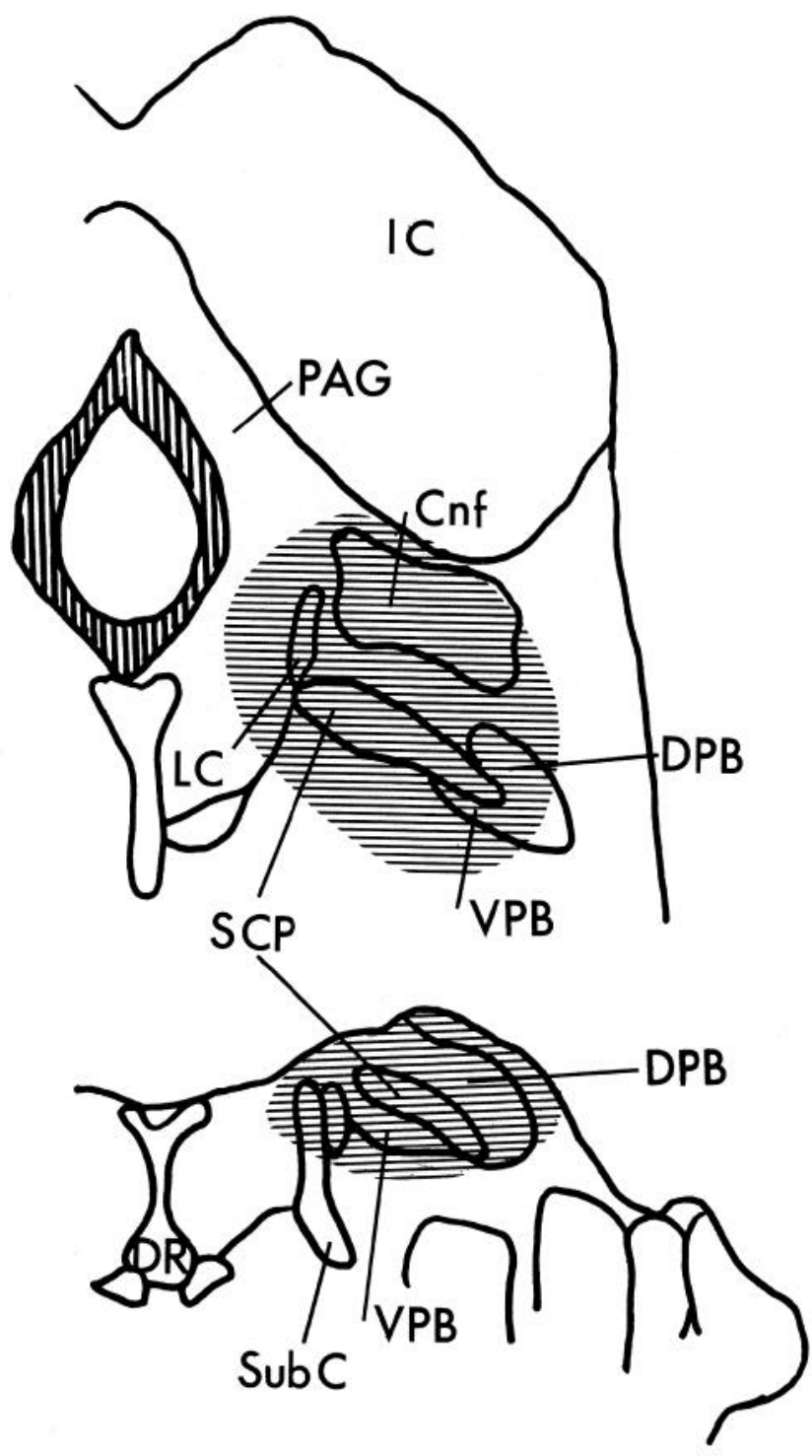

Figure 4. Diagram of the maximum extent of the fluorogold injections in this study. The upper drawing is from a more rostral section $0.2 \mathrm{~mm}$ anterior to the interaural line, and the lower drawing is from a more caudal section $0.3 \mathrm{~mm}$ posterior to the interaural line according to the atlas by Paxinos and Watson (1986). Cnf, cuneiform nucleus; DPB, dorsal parabrachial nucleus; $D R$, dorsal raphe nucleus; $I C$, inferior colliculus; $L C$, locus coeruleus; $P A G$, periaqueductal gray; $S C P$, superior cerebellar peduncle; $S u b C$, subcoeruleus nucleus; $V P B$, ventral parabrachial nucleus.

\section{Discussion}

This study identified an important role for the differential gene regulation of subpopulations of dorsal horn neurons expressing PPT mRNA following peripheral inflammation. RNA blot analysis revealed that PPT mRNA expression in the spinal cord exhibited a significant increase following peripheral inflammation ( $80 \%$ increase), an observation consistent with a previous report (Minami et al., 1989). However, of the many spinal cord dorsal horn neurons expressing PPT mRNA in the different laminae, it appears that a discrete subpopulation is responsible for the increase in message. This observation may reflect the different functional roles of tachykinin peptides in the spinal cord.
The PPT oligonucleotide probe used in this study had a sequence common to $\alpha$-, $\beta$-, and $\gamma$-PPT mRNA and thus could hybridize with all three subsets of PPT mRNA (Krause et al., 1987). Thus, the detection of PPT mRNA in this study may be related to several tachykinin peptides, NKA, NPK, and NP $\gamma$, as well as SP. Recent findings indicate that nearly all dorsal root ganglion neurons that contain immunoreactive NKA also contain SP (Dalsgaard et al., 1985). Radioimmunoassay studies indicate that SP and NPK are distributed in a similar manner in the dorsal root ganglion and the dorsal horn (Ogawa et al., 1985). In addition, release studies using immunoreactive microprobes in a model of acute arthritis show that both SP and NKA are released in the superficial dorsal horn but with a different time course (Hope et al., 1990). The above findings suggest that the peptide products of the PPT gene are distributed in a similar fashion in the dorsal horn. However, we cannot rule out the possibility that unknown posttranslational modification of propeptides might occur in some specific neurons. For the purposes of discussion, however, we will compare our findings of PPT mRNA distribution to that of SP immunoreactivity in the dorsal horn.

Using fluorogold labeling, we identified spinal projection neurons located in lamina I, laminae V/VI, and the LSN. The fluorogold tracer injected in this study covered the parabrachial nucleus in the pons and may be taken up by passing fibers of the spinoreticular, spinothalamic, or spinohypothalamic tracts. However, previous reports have demonstrated that lamina I neurons mainly project to the PBA (mesencephalic parabrachial area) (McMahon and Wall, 1983; Hylden et al., 1986, 1989). Therefore, we assume that most of the double-labeled fluorogold and PPT mRNA-containing neurons, especially those in lamina $\mathrm{I}$, are spinomesencephalic projection neurons.

With the exception of the LSN, several reports have tried and failed to detect SP immunoreactivity in spinal projection neurons (Standaert et al., 1986; Nahin, 1987, 1988; Leah et al., 1988), whereas our ISHH revealed a large number of dorsal horn neurons expressing PPT mRNA. There are many recent reports describing discrepancies between peptide level and mRNA expression of neuropeptides, such as PPT (Warden and Young, 1988), PPE (Harlen et al., 1987; Morita et al., 1990), PPD (Ruda et al., 1988), preproneurotensin (Alexander et al., 1989), and preprocholecystokinin (Burgunder and Young, 1988). In general, more peptide neurons have been detected by ISHH than have been seen using immunohistochemistry in many brain regions. This difference may reflect the sensitivity of each methodology, changes in the time course of transcription versus peptide production, or differences between synthesis and release of peptide.

PPT mRNA expression in the different spinal cord laminae appeared to be selectively regulated following peripheral inflammation and hyperalgesia. In lamina I, many projection neurons expressing PPT mRNA were found ipsilateral and contralateral to the inflamed hindpaw. However, the ipsilateral lamina I projection neurons exhibited a dramatic induction of PPT mRNA following peripheral inflammation. Although we detected that $61 \%$ of all the fluorogold-labeled neurons in lamina I expressed PPT mRNA, the stringent criteria for PPT-labeled neurons used in this study likely resulted in an underestimate of their number.

There are several unique features of lamina I projection neurons. It has been demonstrated that these neurons have a direct projection from lamina I through the dorsolateral funiculus(DLF) to $\mathrm{PBA}$ with a continuing major collateralization to the thalamus 

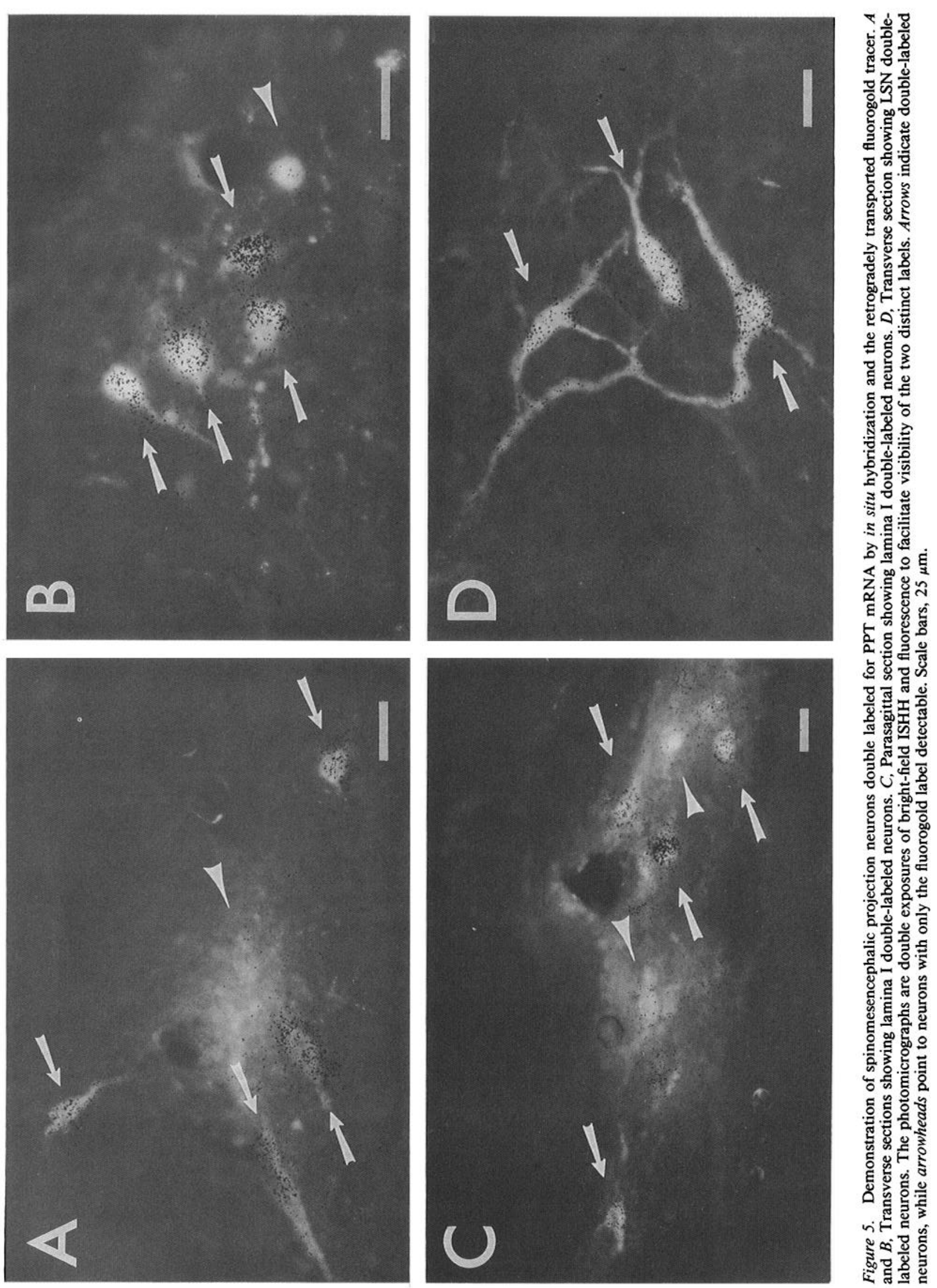


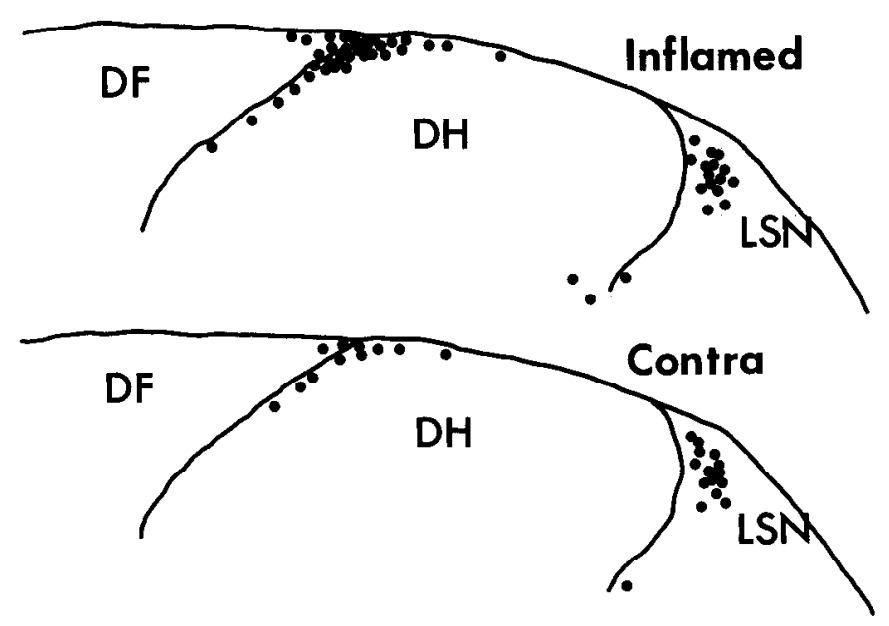

Figure 6. Plots of double-labeled neurons in the L5 spinal cord on the ipsilateral (upper) and contralateral (lower) sides. Plots were combined from nine sections. Note that double-labeled neurons were concentrated under the dorsal root entry zone and their number appeared to increase on the side ipsilateral to the inflammation. Some double-labeled neurons cxtended into Lissauer's tract. $D F$, dorsal funiculus; $D I I$, dorsal horn; $L S N$, lateral spinal nucleus.

(Menetrey et al., 1982; McMahon and Wall, 1983; Wiberg and Blomqvist, 1984; Cechetto et al., 1985; Pannneton and Burton, 1985; Hylden et al., 1986, 1989; Lima and Coimbra, 1989). The cells comprising this system are almost exclusively nociceptive specific, having small receptive fields and slow central conduction velocities (Hylden et al., 1986). These lamina I PBA projection neurons are likely to be involved in activation of autonomic reflexes or pain modulatory mechanisms. Activation of lamina I neurons by noxious stimuli may (1) activate somatovisceral reflexes via input to the PBA of the dorsolateral pons and caudal mesencephalon (Loewy and Burton, 1978; Milner et al., 1984), (2) trigger affective responses to acute pain via connections from the PBA to the hypothalamus (Edwards and deOlmas, 1976; Saper et al., 1978) and amygdala (Saper and Loewy, 1980; Yamano et al., 1988), and (3) activate descending modulatory systems at the level of nucleus cuneiformis and the PAG through connections to the nucleus raphe magnus (Basbaum et al., 1976; Abols and Basbaum, 1981; Beitz, 1982). Our data suggest that the lamina I spinomesencephalic projection neurons with axons in the DLF contain tachykinin peptides. The PPT neurons demonstrated in this study are the first nonopioid neuropeptide-containing projection neurons identificd in lamina I. Since the percentage of neurons expressing PPT mRNA is high and the gene is induced dramatically by nociceptive stimuli, it is likely that tachykinins play an important role in nociception in ascending CNS pathways.

In laminae V/VI, there was an increase in the number of PPT neurons when the ipsilateral and contralateral dorsal horns were compared ( $250 \%$ increase). However, the number of projection neurons expressing PPT mRNA was not significantly different. It is possible that the laminae V/VI neurons with induced PPT mRNA after inflammation either are local circuit neurons or project to brain areas other than the PBA (Harmann et al., 1988; Hylden et al., 1989; Burstein et al., 1990). In this study, a high percentage of projection neurons in the LSN expressed PPT mRNA, an observation consistent with previous reports (Nahin, 1987; Leah et al., 1988). There was no detectable increase in the number or intensity of labeling of PPT neurons in the LSN following inflammation. This observation is somewhat expected since most cells in the LSN are unresponsive to cutaneous input (Menetrey et al., 1980) and the LSN is apparently devoid of primary afferent input (Swett and Woolf, 1985). The functional role of PPT neurons in the LSN is unknown.

Lamina II neurons are for the most part considered to be dorsal horn local circuit neurons. The number of neurons expressing PPT mRNA in lamina II showed a $37 \%$ increase ipsilateral to the inflamed hindpaw (Table 1). Although the lamina II neurons have a high level of constitutive PPT mRNA expression, peripheral inflammation induced a significant increase. There have been few reports speculating on the role of local circuit neurons containing tachykinin peptides, including SP. The large amount of SP in the dorsal horn that is of primary afferent origin makes it difficult to differentiate the action of intrinsic SP from primary afferent SP. Senba et al. (1988) reported that most rat lamina II SP neurons (95\%) colocalized enkephalin (ENK). Dorsal horn ENK neurons have been shown to have synaptic contact with laminae I or V ascending projection neurons (Ruda, 1982; Ruda et al., 1984) and are considered to regulate their activity. Thus, SP in local circuit neurons may also have a modulatory role on noxious signal transmission in conjunction with opioid peptides. Our finding that lamina II neurons expressing PPT mRNA are upregulated by noxious stimuli is the first demonstration of the participation of tachykinins in nociceptive local circuit networks.

\section{References}

Abols IA, Basbaum AI (1981) Afferent connections of the rostral medulla of the rat: a neural substrate for midbrain-medullary interactions in the modulation of pain. J Comp Neurol 201:285-297.

Alexander MJ, Miller MA, Dorsa DM, Bullock BP, Melloni RH, Dobner PR, Leeman SE (1989) Distribution of neurotensin/neuromedin N mRNA in rat forebrain: unexpected abundance in hippocampus and subiculum. Proc Natl Acad Sci USA 86:5202-5206.

Barber RP, Vaughn JE, Slemmon JR, Salvaterra PM, Roberts E, Leeman SE (1979) The origin, distribution and synaptic relationships of substance $P$ axons in rat spinal cord. J Comp Neurol 184:331-352.

Basbaum AI, Clanton CH, Fields HL (1976) Opiate and stimulusproduced analgesia: functional anatomy of a medullospinal pathway. Proc Natl Acad Sci USA 73:4685-4688.

Beitz AJ (1982) The nuclei of origin of brain stem enkephalin and substance $\mathbf{P}$ projections to the rodent nucleus raphe magnus. Neuroscience 7:2753-2768.

Burgunder J-M, Young WS III (1988) The distribution of thalamic projection neurons containing cholecystokinin messenger RNA, using in situ hybridization histochemistry and retrograde labeling. Mol Brain Res 4:179-189.

Burstein R, Cliffer KD, Giesler GJ Jr (1990) Cells of origin of the spinohypothalamic tract in the rat. J Comp Neurol 291:329-344.

Carter MS, Krause JE (1990) Structure, expression, and some regulatory mechanisms of the rat preprotachykinin gene encoding substance $\mathrm{P}$, neurokinin $\mathrm{A}$, neuropeptide $\mathrm{K}$, and neuropeptide $\gamma$. J Neurosci 10:2203-2214.

Cechetto DF, Standaert DG, Saper CB (1985) Spinal and trigeminal dorsal horn projections to the parabrachial nucleus in the rat. J Comp Neurol 240:153-160.

Dalsgaard CJ, Haegerstrand A, Theodorsson-Norheim E, Brodin E, Hokfelt T (1985) Neurokinin A-like immunoreactivity in rat primary sensory neurons; coexistence with substance P. Histochemistry 83:37-39.

Davis BM, Krause JE, McKelvy JF, Cabot JB (1984) Effects of spinal lesions on substance $P$ levels in the rat sympathetic preganglionic cell column: evidence for local spinal regulation. Neuroscience 13:13111326.

DeLeon M, Welcher AA, Suter U, Shooter EM (1991) Identification of transcriptionally regulated genes after sciatic nerve injury. $J$ Neurosci Res 29:437-448. 
Edwards SB, deOlmos JS (1976) Autoradiographic studies of the projections of the midbrain reticular formation: ascending projection of nucleus cuneiformis. J Comp Neurol 165:417-432.

Gibson SJ, Polak JM, Bloom SR, Wall PD (1981) The distribution of nine peptides in rat spinal cord with special emphasis on the substantia gelatinosa and on the area around the central canal (lamina X). J Comp Neurol 201:65-79.

Hammond DL, Ruda MA (1991) Developmental alterations in the distribution of immunoreactive calcitonin gene-related peptide, substance $P$ and fluoride-resistant acid phosphatase in the spinal cord of the rat after neonatal administration of capsaicin: relationship to nociceptive threshold. J Comp Neurol 312:436-450.

Hargreaves K, Dubner R, Brown F, Flores C, Joris J (1988) A new and sensitive method for measuring thermal nociception in cutaneous hyperalgesia. Pain 32:77-94.

Harlen RE, Shivers BD, Romano GJ, Howells RD, Pfaff DW (1987) Localization of preproenkephalin mRNA in the rat brain and spinal cord by in situ hybridization. J Comp Neurol 258:159-184.

Harmann PA, Carlton SM, Willis WD (1988) Collaterals of spinothalamic tract cells to the periaqueductal gray: a fluorescent doublelabelling study in the rat. Brain Res 441:87-97.

Henry JL (1976) Effects of substance P on functionally identified units in cat spinal cord. Brain Res 114:439-451.

Hokfelt T, Kellerth JO, Niosson G, Pernow B (1975) Substance P: localization in the central nervous system and in some primary sensory neurons. Science 190:889-890.

Hope PJ, Jarrott B, Schiable H-G, Clarke RW, Duggan AW (1990) Release and spread of immunoreactive neurokinin $A$ in the cat spinal cord in a model of acute arthritis. Brain Res 533:292-299.

Hunt SP, Kelly JS, Emson PC, Kimmel JR, Miller RJ, Wu J-Y (1981) An immunohistochemical study of neuronal populations containing neuropeptides or gamma aminobutyrate within the superficial layers of the rat dorsal horn. Neuroscience 6:1883-1898.

Hylden JLK, Hayashi H, Dubner R, Bennett GJ (1986) Physiology and morphology of the lamina I spinomesencephalic projection. J Comp Neurol 247:505-515.

Hylden JLK, Anton F, Nahin RL (1989) Spinal lamina I projection neurons in the rat: collateral innervation of parabrachial area and thalamus. Neuroscience 28:27-37.

Iadarola MJ, Brady LS, Draisci G, Dubner R (1988) Enhancement of dynorphin gene expression in spinal cord following experimental inflammation: stimulus specificity, behavioral parameters and opioid receptor binding. Pain 35:313-326.

Kotani H, Hoshimaru M, Nawa H, Nakanishi S (1986) Structure and gene organization of bovine neuromedian $K$ precursor. Proc Natl Acad Sci USA 83:7074-7078.

Krause JE, Chirgwin JM, Carter MS, Xu ZS, Hershey AD (1987) Three rat preprotachykinin mRNAs encode the neuropeptides substance $P$ and neurokinin A. Proc Natl Acad Sci USA 84:881-885.

Leah J, Menetrey D, dePommery J (1988) Neuropeptides in long ascending spinal tract cells in the rat: evidence for parallel processing of ascending information. Neuroscience 24:195-207.

Lima D, Coimbra A (1989) Morphological types of spinomesencephalic ncurons in the marginal zonc (lamina I) of the rat spinal cord, as shown after retrograde labelling with cholera toxin subunit B. J Comp Neurol 279:327-339.

Loewy AD, Burton H (1978) Nuclei of the solitary tract: efferent projections to the lower brain stem and spinal cord of the cat. J Comp Neurol 181:421-450.

Maggio JE (1988) Tachykinins. Annu Rev Neurosci 11:13-28.

McMahon SB, Wall PD (1983) A system of rat spinal cord lamina I cells projecting through the contralateral dorsolateral funiculus. J Comp Neurol 214:217-223

Menetrey D, Chaouch A, Besson J-M (1980) Location and properties of dorsal horn neurons at origin of spinoreticular tract in lumbar enlargement of the rat. J Neurophysiol 44:862-877.

Menetrey D, Chaouch A, Binder D, Besson J-M (1982) The origin of the spinomesencephalic tract in the rat: an anatomical study using the retrograde transport of horseradish peroxidase. J Comp Neurol 206:193-207.

Millan MJ, Millan MH, Czlonkowski A, Hollt V, Pilcher CWT, Herz A, Colpaert FC (1986) A model of chronic pain in the rat: response of multiple opioid systems to adjuvant-induced arthritis. J Neurosci 6:899-906.

Milner TA, Joh TH, Miller RJ, Pickel VM (1984) Substance P, neu- rotensin, enkephalin, and catccholaminc-synthcsizing enzymes: light microscopic localizations compared with autoradiographic label in solitary efferents to the rat parabrachial region. J Comp Neurol 226: 434-447.

Minami M, Kuraishi Y, Kawamura M, Yamaguchi T, Masu Y, Nakanishi S, Satoh M (1989) Enhancement of preprotachykinin A gene expression by adjuvant-induced inflammation in the rat spinal cord: possible involvement of substance P-containing spinal neurons in nociception. Neurosci Lett 98:105-110.

Molander C, Xu Q, Grant G (1984) The cytoarchitectonic organization of the spinal cord in the rat. I. The lower thoracic and lumbosacral cord. J Comp Neurol 230:133-141.

Morita Y, Zhang J-H, Hironaka T, Tateno E, Noguchi K, Sato M, Kiyama H, Tohyama M (1990) Postnatal development of preproenkephalin mRNA containing neurons in the rat lower brainstem. J Comp Neurol 292:193-213.

Nagy JI, Vincent SR, Staines WMA, Reisine TD, Yamamura HI (1980) Neurotoxic action of capsaicin on spinal substance $P$ neurons. Brain Res 186:435-444.

Nahin RL (1987) Immunocytochemical identification of long ascending peptidergic neurons contributing to the spinoreticular tract in the rat. Neuroscience 23:859-869.

Nahin RL (1988) Immunocytochemical identification of long ascending, peptidergic lumbar spinal neurons terminating in either the medial or lateral thalamus in the rat. Brain Res 443:345-349.

Nahin RL, Hylden JLK, Iadarola MJ, Dubner R (1989) Peripheral inflammation is associated with increased dynorphin immunoreactivity in both projection and local circuit neurons in the superficial dorsal horr of the rat lumbar spinal cord. Neurosci Lett 96:247-252.

Naranjo JR, Mellstrom B, Achaval M, Sassone-Corsi P (1991) Molecular pathway of pain: Fos/Jun-mediated activation of a noncanonical AP-1 site in the prodynorphin gene. Neuron 6:607-617.

Nawa H, Hirose T, Takashima H, Inayama S, Nakanishi S (1983) Nucleotide sequences of cloned cDNAs for two types of bovine brain substance $P$ precursor. Nature 306:32-36.

Noguchi K, Morita Y, Kiyama H, Sato M, Ono K, Tohyama M (1989) Preproenkephalin gene expression in the rat spinal cord after noxious stimuli. Mol Brain Res 5:227-234.

Noguchi K, Kowalski K, Traub R, Solodkin A, Iadarola MJ, Ruda MA (1991) Dynorphin expression and fos-like immunoreactivity following inflammation induced hyperalgesia are colocalized in spinal cord neurons. Mol Brain Res 10:227-233.

Nuguchi K, Dubner R, Ruda MA (1992) Preproenkephalin mRNA in spinal dorsal horn neurons is induced by peripheral inflammation and is colocalized with Fos and Fos-related proteins. Neuroscience 46:561-570.

Ogawa T, Kanazawa I, Kimura S (1985) Regional distribution of substance $\mathrm{P}$, neurokinin $\alpha$ and neurokinin $\beta$ in rat spinal cord, nerve roots and dorsal root ganglia and the effects of dorsal root section or spinal transection. Brain Res 359:152-157.

Panneton WM, Burton H (1985) Projections from the paratrigeminal nucleus and the medullary and spinal dorsal horns to the peribrachial area in the cat. Neuroscience 15:779-797.

Paxinos G, Watson C (1986) The rat brain in stereotaxic coordinates. New York: Academic.

Pernow B (1983) Substance P. Pharmacol Rev 35:85-141.

Piercey MF, Dobry PJK, Schroeder LA, Einspahr FJ (1981) Behavioral evidence that substance $\mathbf{P}$ may be a spinal cord sensory neurotransmitter. Brain Res 210:407-412.

Randic M, Miletic V (1977) Effect of substance $\mathbf{P}$ in cat dorsal horn neurons activated by noxious stimuli. Brain Res 128:164-169.

Ruda MA (1982) Opiates and pain pathways: demonstration of enkephalin synapses on dorsal horn projection neurons. Science 215: 1523-1525.

Ruda MA, Coffield J, Dubner R (1984) Demonstration of postsynaptic opioid modulation of thalamic projection neurons by the combined techniques of retrograde horseradish peroxidase and enkephalin immunocytochemistry. J Ncurosci 4:2117-2132.

Ruda MA, Iadarola MJ, Cohen LV, Young WS III (1988) In situ hybridization histochemistry and immunocytochemistry reveal an increase in spinal dynorphin biosynthesis in a rat model of peripheral inflammation and hyperalgesia. Proc Natl Acad Sci USA 85:622-626.

Saper CB, Loewy AD (1980) Efferent connections of the parabrachial nucleus in the rat. Brain Res 197:291-317.

Saper CB, Swanson LW, Cowen WN (1978) The efferent connections 
of the anterior hypothalamic area of the rat, cat and monkey. J Comp Neurol 182:575-600.

Senba E, Yanaihara C, Yanaihara N, Tohyama M (1988) Co-localization of substance $P$ and Met-enkephalin-Arg-Gly-Leu in the intraspinal neurons of the rat, with special reference to the neurons in the substantia gelatinosa. Brain Res 453:110-116.

Seybold VS, Hylden JLK, Wilcox GL (1982) Intrathecal substance P and somatostatin in rats: behaviors indicative of sensation. Peptides $3: 49-54$.

Standaert DG, Watson SJ, Houghten RA, Saper CB (1986) Opioid peptide immunoreactivity in spinal and trigeminal dorsal horn neurons projecting to the parabrachial nucleus in the rat. J Neurosci 6 : 1220-1226.

Swett JE, Woolf CJ (1985) The somatotopic organization of primary afferent terminals in the superficial laminae of the dorsal horn of the rat spinal cord. J Comp Neurol 231:66-77.

Warden MK, Young WS III (1988) Distribution of cells containing mRNAs encoding substance $\mathrm{P}$ and neurokinin $\mathrm{B}$ in the rat central nervous system. J Comp Neurol 272:90-113.
Wiberg M, Blomqvist A (1984) The spinomesencephalic tract in the cat: its cells of origin and termination pattern as demonstrated by the intraaxonal transport method. Brain Res 291:1-18.

Willcockson WS, Chung JM, Hori Y, Lee KH, Willis WD (1984) Effects of iontophoretically released peptides on primate spinothalamic tract cells. J Neurosci 4:741-750.

Yamano M, Millyard CJ, Girgis S, MacIntyre I, Emson PC, Tohyama $M$ (1988) Presence of a substance P-like immunoreactive neuron system form the parabrachial area to the central amygdaloid nucleus of the rat with reference to coexistence with calcitonin gene-related peptide. Brain Res 451:179-188.

Young WS III, Bonner TI, Brann MR (1986) Mesencephalic dopamine neurons regulate the expression of neuropeptide mRNAs in the rat forebrain. Proc Natl Acad Sci USA 83:9827-9831.

Zimmermann M (1983) Ethical guidelines for investigations of experimental pain in conscious animals. Pain 16:109-110. 